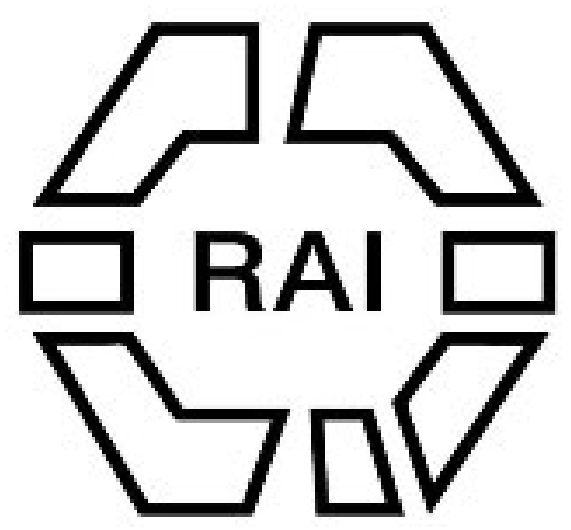

Notes on the Ethnography of the Ba-Mbala

Author(s): E. Torday and T. A. Joyce

Source: The Tournal of the Anthropological Institute of Great Britain and Ireland, Vol. 35

(Jul. - Dec., 1905), pp. 398-426

Published by: Royal Anthropological Institute of Great Britain and Ireland

Stable URL: http://www.jstor.org/stable/2843076

Accessed: 16/06/2014 18:09

Your use of the JSTOR archive indicates your acceptance of the Terms \& Conditions of Use, available at http://www.jstor.org/page/info/about/policies/terms.jsp

JSTOR is a not-for-profit service that helps scholars, researchers, and students discover, use, and build upon a wide range of content in a trusted digital archive. We use information technology and tools to increase productivity and facilitate new forms of scholarship. For more information about JSTOR, please contact support@jstor.org. 


\title{
NOTES ON THE ETHNOGRAPHY OF THE BA-MBALA.
}

\author{
By E. Torday and T. A. Joyce, M.A.
}

[With Plates XXVIII-XXX.]

The Ba-Mbala are a Bantu tribe inhabiting the tract of country between the rivers Inzia (Saie) and Kwilu. They are practically an unknown people, since, though their name is familiar to anthropologists, virtually nothing has been recorded concerning their ethnography, and the portion of the map representing their country is an absolute blank, save for the conjectured courses of the two rivers mentioned above.

On the north-east round to the north-west they are in touch with the Ba-Huana, Ba-Yanzi, and Ba-Songo: on the west and south-west are found the Ba-Samba, Wa-Ngongo, and Ba-Yakka; and the Wa-Ngongo occur again on their western borders.

They say of themselves that they are an inmigrant tribe, and that they were driven from their country south of the Wamba by the "Mulua," a people, "composed of blacks and half-blacks, armed with guns, not such as we have (flint-locks). They killed many people, and the rest were driven away as slaves; so we fled to the north, others again to the north-east. We do not know what became of the latter." It is worth while mentioning, in connection with this account, that there is a tribe in the Kasai district also called Ba-Mbala ; it may be possible that these represent the section mentioned as being driven towards the north-east.

The term "Mulua" appears to mean, simply, rebels, so it does not seem likely that very much concerning their origin can be extracted from the native report. Arrived at their present abode, the Ba-Mbala obtained possession of the country by purchase from the Ba-Songo and Ba-Yanzi, who had previously driven out the Ba-Bunda, with the exception of a few in the interior. There now seems some likelihood of their being ousted from their present position by the Ba-Yakka, who are encroaching on the south, and who, from the fact that they recognize a single paramount chief, possess a stronger social organisation.

Perhaps the chief point of interest in connection with the Ba-Mbala is the extremely primitive stage of culture in which they live. Though they are comparatively new arrivals in the country which they now inhabit, and which they have reached from the south-west, they have acquired their chief crafts and industries from the tribes living on their northern and north-western borders. Basketwork they have learnt from the Ba-Yanzi, pottery and metallurgy from the Ba-Huana (from the latter also the castration of animals). Their implements are few and primitive, and their sole weapon is the bow. Their social system is 
equally elementary, their villages are ruled by independent plutocratic chiefs, and no cohesion exists amongst them except such as is afforded by compacts between neighbours against murder. Slavery exists, but seems to be little more than nominal, and the difference between slave and freeman very slight. What might be considered a faint tendency towards a matriarchal system is to be found in the fact that a married man considers his father-in-law to rank before his father, and will often take up his abode in his wife's village and fight for it, even against his own relations. The existence of the hereditary class Muri, distinguished by a cap and bracelet, labouring under the disadvantage (serious among a people so frankly cannibal) of being prohibited from eating human flesh, and possessing, apparently, no compensating privileges, seems somewhat surprising in the midst of a culture so elementary.

As night be expected from the native account of their migration, the Ba-Mbala appear to be connected with the tribes of Angola, and it would seem only natural that the ethnic disturbances caused by the early Portuguese invaders, aggravated as these were by the continual raids in all directions made by various wandering tribes of marauders under chiefs styled Jaga, should have forced a more primitive and less warlike people to migrate inland. Indeed, in Purchas' account of Andrew Battell's adventures" it will be found that the Gagas, "marched towards the Province of Bambala, to a great Lord that is called Calicansamba," and their raids extended, subsequently to the Kwango, but the early accounts are so confused that not very much can be extracted from them.

Ladislaus Magyar, ${ }^{2}$ in tracing the history of the Kimbunda (Binbunda), whom he describes as inhabiting the country south of the Kwanza and extending over five degrees of latitude and longitude, states that they came from the land of Morofu in the north-east, fighting their way to the banks of the Luando. There they fell under the influence of the Jaga, and for some time devoted themselves entirely to raiding and cannibalism. At last certain of the chiefs, seeing that the taste for human flesh was the cause of continual intertribal strife, and fearing for the future of the race, formed a society the members of which were sworn not to indulge in anthropophagy. This society was kept secret owing to fear of the Jaga and their adherents, but at length civil war broke out, and the chiefs and their followers who had joined the organisation were forced to cross the Kwanza, south of which they settled and spread over the tract already indicated. The ostensible cause of the war was the defection of a certain section of the tribe, who, preferring to follow the Jaga, refused to obey the orders of the Soba, or head-chief of the Kimbunda, when he commanded them to relinquish their raiding habits and settle down to cultivation. Now if the members of the anti-cannibalistic band were sufficiently numerous to obtain a secure footing south of the Kwanza, it seems probable that the society must have had a wide sphere of influence, and it is quite likely that this influence may have extended to the Jinga further north, who

1 Purchas his Pilgrimes (1625), II, vii, 974.

2 Reisen in Süi-Afrika, trans. by J. Hunfalvy, pp. 265 foll. 
may or may not have been racially connected with the Kimbunda, but who had undoubtedly also come within the sphere of Jaga influence. It is interesting to notice that, in later times at any rate, the Ngola or chief of this people appointed subchiefs to whom he gave, as sign of authority, a cap, called kajinga, and a bracelet, termed malunga, and that these sub-chiefs were distinguished by a special title, here Kalunga. ${ }^{1}$ An attractive theory might be formulated by assuming that certain of these had joined the organisation mentioned above, and had been driven out, in this case to the north-east. If this were granted, it would not be difficult to believe that the insignia of chieftainship had become hereditary, while the actual power, owing to economic reasons, had fallen into the hands of the rich. As the true circumstances of the migration gradually fell into oblivion, the prohibition against human flesh would become mystically attached to the holders of the old emblems of chieftainship, since it would have been the chiefs who, in the first place, would have been the members of the society, and not necessarily their followers; these would have merely followed the lead of their chiefs. But however satisfactorily this theory might account for the presence of the Muri sect among the Ba-Mbala, it is to be feared that it rests upon too insecure a foundation to be considered, in the present state of our knowledge upon the subject, anything more than the merest conjecture; moreover, the difference in terminology as regards bracelet, cap, etc., is against it. Still, in any case, the parallel between the Jinga sub-chiefs and the Muri of the Ba-Mbala is interesting, and it is noticeable that the social system of Magyar's Kimbunda, though more advanced than that of the Ba-Mbala, is nevertheless remarkably similar in many respects.

It may, perhaps, be as well to mention a few points of similarity between the Ba-Mbala and the peoples of Portuguese West Africa, though it would of course be unwise to lay too much stress upon them. Throughout practically the whole of Angola, among the Mushi-Congo, Ba-Congo, Ba-Ngala, Binbunda, etc., the poison ordeal is employed as a means of discovering the malign influence which is supposed to be responsible for every natural death: the poison appears to be the same, and the guilt or innocence of the accused is decided in a similar way. Purchas, ${ }^{2}$ speaking of Loango, adds that the bystanders, when the victim shows signs of being overcome by the poison, "cry, Undoke, Undoke, that is, naughtie Witch," which is the same word as the term Doki used by the Ba-Mbala of a person possessed by Moloki. The usual system of government, throughout the parts of this country traversed by Capello and Ivens ${ }^{3}$ and by Wissmann, ${ }^{4}$ seems to be by petty village chiefs (among the Ba-Kongo called Mfumu), ${ }^{5}$ often independent, but sometimes under the suzerainty of a head-chief who controls several villages. Inheritance by the sister's son is found among the Mushi-Kongo, Ba-Kongo, Ba-Ndombe, Bondo, Kalunda, Binbunda, etc.; and Purchas, ${ }^{6}$ in his account of

1 Capello and Ivens, From Benguella to the Territory of Yacca, vol. ii, p. 54.

- Purchas his Pilgrimage (1613) I, vii, 10, p. 875.

${ }^{3}$ loc. cit.

4 Im Innern Afrikas.

5 Baumann, Mit. Ant. Ges., Wien, xvii, 165.

- Purchas his Pilgrimes (1625!, II, vii, 981. 
Andrew Battell, tells how "The Towne of Longo . . . is governed by four Princes, which are the King's sisters' sonnes. For the King's sonnes never come to be Kings." It is rather surprising that circuncision, so common throughout Angola, is not practised by the Ba-Mbala.

Turning to the east, it is to be observed that the only people who show any similarity with the Ba-Mbala are the Ba-Ngodi and Ba-Dinga described by Wissmann ${ }^{1}$ as inhabiting the southern bank of the Kasai. Both are keen traders (Wissmann compares them to the Kioque in this respect), both frequently ornament the forehead with a long transverse scar, both carry the grooved bow characteristic of the Ba-Mbala, ${ }^{2}$ and, finally, the huts of the former are rectangular, composed of palmleaf-ribs with a rectangular door $2 \mathrm{~m}$. from the ground, reached by "eine Bank oder tischartige Erhohung;" and Wissmann adds "Die Hutten wichen in ihrem Bau wesentlich von denen ab, welche wir bisher gesehen hatten." So little information is accessible concerning the tribes inhabiting the whole tract between the Wamba and the Kasai, that it is useless at present to enter into any discussion as to the relation between the Ba-Mbala and the peoples to the east of their territory, but the similarity between the peculiar bows and huts of the Ba-Ngodi and those of the Ba-Mbala is at least interesting. With these few words of introduction it will be best to proceed forthwith to the information collected by Mr. Torday during the past year concerning the ethnography of the Ba-Mbala.

\section{Clothing and ORNament.}

The clothing of both sexes consists of native made palm-cloth, Kipussu, of which a strip about a yard in length and a half-a-yard in width (in the case of the women, a trifle less), is worn round the waist, leaving the upper half of the buttocks bare at the back (a fashion found among the Baluba also). This cloth is often fastened by a girdle of similar cloth, or grass coloured with red clay. European cloth and beads are also seen, but not in any quantity. The skins of goats and (rarely) antelopes are cut into aprons and worn in front by men, they are simply dried in the sun and oiled; the hair is not removed. No special covering or ornament for the genitals is worn, but the women wear a string of beads under the waist-cloth, according to the regular Bantu fashion. Garments are sewn with eyed iron needles of native make, and palm-fibre thread. The head is sometimes covered with a piece of red Kipussu, to hide baldness or white hairs, and this covering is also used by the special sect of Muri, described later. A man who has slain a great enemy wears the finger-bones and penis of the latter wrapped in a piece of cloth, on his head; this is considered a great fetish and is termed Pungu.

Hair is allowed to grow upon the top of the head, in the form of a cap, the rest is shaved and painted black with soot and palm oil. Some wear hair at the back of the head only, made up into tresses with soot and palm oil. The moustache is usually shaved; the beard, which grows on the point of the chin only, often

$$
1 \text { Loc. cit., pp. 359-60. } \quad 2 \text { See illustration on p. } 416 .
$$


attains considerable length, but is bound up under the chin, and pieces of clay are often hidden in the knot to give it a more important appearance. The eyebrows are shaved; hair under the arms is pulled out; women shave the pudenda, men do not. Circumcision is not practised, but is known, for it is found among neighbouring tribes.

Ears with perforated lobes occur, but it does not seem that ornaments are worn in them. ${ }^{1}$ Nose and lip ornaments are unknown.

Combs, made of a number of wooden teeth bound together, are worn in the hair by both sexes and form useful appliances for scratching the head.

Bracelets, of European imported brass, are worn in great numbers. These are not meant to be removed. Iron bracelets, of local make, are occasionally worn on the arm by men, but are rare. A special bracelet called Mwena, characteristic of the peculiar Muri sect, will be mentioned later (p. 409).

Rings of imported copper and brass, of spiral shape and easily removable, are worn on the fingers; the great toe is also often ornamented with a ring.

Beads are worn by both sexes.

Teeth, human, ape and leopard (the last usually imitations), are reserved for men.

Horns.-Small antelope horns, as well as imitations made of imported tin, are worn by men suspended round the neck.

Painting.-The favourite colour is red; cloth and body are coloured with red clay, in place of the well-known Tukula wood, which is here too expensive, being imported from the Kasai. The object of painting the body is, admittedly, to increase beauty, but the practice is also followed by mourners, the women using brown clay, the men soot.

Scars are made upon the face and body at puberty, and project considerably above the surface of the skin. The natives deny that any foreign matter is inserted in the wounds, but say that the healing process is artificially retarded. The commonest patterns are, among men, the following:-A line running over the forehead from the exterior corner of one eye to that of the other; a line more or less straight, across the chest, about one inch broad and often more than an inch in relief, and a lozenge pattern round the navel. Women seldom ornament the face in this way, but decorate the arm and stomach with a series of lozenges.

Tattooing is rare, but is found occasionally; the design is usually very simple, consisting of a quadrilateral on the arm from 7 to $13 \mathrm{~cm}$. square. The instrument is composed of three or four needles, and the pigment used is decayed rubber.

No post-mortem scarification or tattooing is practised.

\section{Food.}

The ordinary food consists of manioc flour, mixed with water and boiled; maize is very seldom used. Manioc leaves are also eaten, prepared with palm oil and native pepper (pili-pili); this dish is called Gato. As regards domestic animals, goats, pigs and dogs all find their way into the pot; as to other animals,

1 "I have never seen ornaments worn in the ears." 
everything that liveth and moveth, from man down to grasshoppers and ants, including the common brown owl, which is despised by the neighbouring tribes, is food for the Ba-Mbala. One animal, however, must be mentioned as an exception, the frog. This is all the more remarkable because this animal is eaten by Ba-Huana women, although should a man of that tribe be found eating one, he is laughed to scorn. Hence the name Yunda "froggies," which the Ba-Mbala apply to the Ba-Huana.

The following are regarded as especial delicacies: Human flesh (called Misuni), a thick white worm found in palm-trees, rats, locusts, blood boiled with cassava flour. The following are forbidden to women:-Human flesh, goat's flesh, hawks, vultures, small birds, snakes, parrots, crows, and all animals hunted with weapons, except the antelope and a small rat which is not uncommon and is called "Zibiri" in French. Certain restrictions as to food are observed also by the Muri (see later).

Although human flesh is forbidden to women, nevertheless, on the evidence of an old Mo-Mbala woman, there are many who partake of it in secret. "When the sun shines we say:- 'Eat Misuni? Bah! Never!' and we spit on the ground; but when night comes we steal to the grave and take our share as well as the men."

The only stimulant used is the kola-nut, which is eaten by the rich in great quantities. Practically the only oil used is that obtained from the palm-nut, though in quite exceptional cases, ground-nut oil is found. Spices are used, e.g. a native cayenne, and a kind of black pepper, also native, called $K e f$.

Salt is particularly prized, and is also used as currency; it is made from the ashes of water-plants, but imported salt, especially that in crystalline form, is greatly preferred. These crystals, when obtained, are perforated and strung on a string, which is then simply dipped into the pot containing the food. The natives believe that imported salt falls from heaven in Europe. Salt is eaten as a stimulant on a journey, and salt water is also drunk on these occasions. Geophagy is common, as is the case among the neighbouring. Ba-Yanzi ; the earth eaten is said to be a cure for stomach-ache, it has an astringent taste, and if the hand is buried in it for some time, it becomes quite wrinkled.

Food is never eaten raw, though it is preferred high; human and other flesh is often smoked, but is always cooked before being eaten. The food is simply boiled in water or palm oil in the ordinary pot, Dzungu (Plate XXVIII, Fig. 3), which is cleaned before use; ovens are not found. Cooking is done in the house by women alone; leaven is unknown. The native drink is Makana, or palm wine, obtained from the elaïs. A deep cut is made near the top of the tree, and a gourd is attached, into which the sap flows. The regular mealtimes are early morning and evening, but a native will eat at any time during the day that he feels hungry.

Fire is procured by means of flint (found in rivers), steel, and tinder obtained from the palm-tree; dead wood is used as fuel. (For the manufacture of fire-steels, see Metallukgy.)

Domestic Animals.-Under the heading of food may be considered the subject of domestic animals. Besides those mentioned above, there is the dog, the small 
breed common in Central Africa, thin, red-haired, bad-tempered, with a voice like the crowing of a cock. They are used in hunting, when rattles are attached to them (Plate XXVIII, Fig. 7), as food, and as general scavengers. If a dog steals it is attached to a $T a k a$ (see under WAR), just like a man, and appears to feel its position keenly; the owner of an animal is responsible for any damage it may do. Goats and pigs are slaughtered for food by being clubbed, but the former are often skinned alive, a process which is said to improve the quality of the meat; fowls are taken by the head and whirled round until the body breaks away. Animals are generally well-treated by the natives, and young dogs are fed by the owner, who chews their food and spits it into their mouths; otherwise, as regards food and housing, animals are left to shift for themselves. Both goats and pigs are castrated, and the man who performs the operation must abstain from his wife on the night previous, or his death is assured; he then paints and oils himself liberally and proceeds to operate. Salt is rubbed into the wound, and, in the case of pigs, the cavity is filled with sand. They are very skilful, and it seems that animals hardly ever $\operatorname{die}^{1}$ as the result of the operation, which they have learnt from the Ba-Huana.

Cannibalism may be described as an every-day occurrence, and, according to the natives themselves, is based on a sincere liking for human flesh, which, when used for food, is called Misuni. Natives speak quite freely about it, though of course in the presence of state officials, judges, etc., they are naturally silent on the subject; but an ordinary trader can obtain any information on this head, and is sometimes offered the opportunity of experiencing the flavour of the delicacy; in fact, if an ordinary individual wished to assist at a cannibal feast he would not find any great difficulty in doing so, though if he attempted to interfere he would be killed on the spot. Enemies killed in war, people buried alive after the poison test or dying in consequence of it, relations (except father, mother, children, uncles, or aunts), and sometimes foreign slaves, are all eaten; in fact, any corpse which is not in the last stages of decomposition is considered a dainty.

Victims killed for cannibalistic purposes are often buried for two days before being eaten, during which period a fire is kept burning on the grave; the body is then exhumed and cooked with manioc flour. Every part of the body, including the blood, and with the exception of the penis, is consumed; the last, in the case of an enemy killed in war, is wrapped in a piece of cloth with his finger-bones and worn on the head of the slayer, forming the Pungu fetish mentioned above (p. 401). The bones are in some cases hung on a tree in the centre of the village, but are often simply thrown away.

Vessels in which Misuni has been cooked are broken and the pieces thrown away. Cannibalism accompanies the ceremony by which a kind of alliance is established between chiefs of the same region (p. 409). Women, and the peculiar class known as Muri, are not allowed to eat human flesh (but see p. 403).

Tobacco is grown in great quantities, and used, when green, as snuff, or, when dried, for smoking without further preparation. Women rarely make use of

1 "I have never known an animal die." 
tobacco, though occasionally young women take snuff and the elderly indulge in a pipe. Snuff is prepared by pounding the green leaf in a small wooden mortar with a long pointed handle, which is driven into the ground (Plate XXVII, Fig. 2). Snuff is offered between acquaintances; all Ba-Mbala men have the upper lip thickly plastered with snuff, giving them the appearance of wearing a green moustache; the idea is, possibly, to prolong the pleasure. There are three patterns of pipe: (a) a pipe of European form, Kinzu, (b) a pipe made from a gourd, Motobo, and (c) a pipe made of bamboo, Fangu (Plate XXVIII, Fig. 1). The two latter have pottery bowls of native make. When the natives smoke in company the pipe is passed from hand to hand. Hemp-smoking is rare, though it does exist; but it is considered a bad habit by the natives. Drunkenness is mentioned with respect as a sign of wealth.

\section{AGRICULtURE.}

Ground for cultivation is cleared by the men, after which all other work is left to the women, whose sole implement is the dembn, or better, terio, an iron hoe, triangular and tanged, with the value, as currency, of three fowls or 300 djimbu. Manioc, called soko, bananas, tichipi, plantains, mipindi, sweet potatoes, kata n'dunge, small haricots, makundu, and ground nuts, n'zuku, are all cultivated, and tobacco is to be found in every village. Fresh ground is cleared yearly, and the crop belongs to the head of the family; irrigation is never practised. Charms of a simple character, such as empty egg-shells, a bone, or a broken pot, are placed in the fields as a guard against thieves.

\section{SPORT.}

Fishing is carried on by women by means of wicker traps, but there is very little water in the country.

Hunting is inconsiderable; for a long time game has been extremely scarce in the country, in fact, a man who kills an antelope is talked of for many miles round. Rats of all kinds form the principal game, and are caught in traps or shot with blunt arrows. Great' communal hunts take place once a year, in June and July, when the game is driven by setting fire to the dry grass. It is considered the greatest offence against a village to burn its grass, otherwise no strict bounds are observed. After the hunt, if successful, a present, consisting of horns or a skull, is made to the village fetish, if failure has resulted, the unhappy fetish is severely reprimanded by the magician.

Bows and arrows are the only weapons used in hunting ${ }^{1}$; the bow is called butc, while the generic term for an arrow is betutu. Arrows are of several patterns; for small game the points are of wood hardened in the fire, the tomo has one point, and the kikashi four. For bigger game, war arrows, with iron heads, called mivi, are used (Plate XXVIII, Fig. 8). The use of poison, either in hunting or in war,

1 "Once only have I come across a native who used his flint-lock for killing game, in this case guinea-fowl. He used to hide himself in the bush, so that the muzzle of his gun was the only thing visible; this he used to move up and down, and the guinea-fowl would come close to see what it was, when he would bag several with a single shot. At least this was his account." 
is unknown. The natives are rather poor shots, and are not capable of doing much harm at a range of over 50 yards. Dogs are employed in hunting and are cleverer than their masters, and often succeed in taking partridges; a wooden rattle, shaped like a hawk-bell, and containing a loose stone as clapper is hung between the hind legs of a dog when driving game (Plate XXVIII, Fig. 7). The man who has killed a bird tries to sneak away without being observed, and does not return until he has eaten it, for fear lest another may wish to share in his prey. Wooden whistles are used in hunting, and are often provided with a finger-hole, by which the note can be altered (Plate XXIX, Fig. 2).

\section{Crafts.}

String is made of palm-fibre (Pussu) twisted; sewing-thread, of the same, finely divided.

Basketwork, an art learnt from the Ba-Yanzi, is highly appreciated, and the manufacture is confined to men. The generic term for a basket is kisangi; the quadrangular pattern, made of a water-plant, is called mahapa. The ordinary pattern is circular, on a quadrangular wooden base, and is termed muteke; the cover, which fits closely, is called bango (Plate XXVIII, Fig. 4). Small baskets, called katekwa, are used as purses to contain shell-currency (djimbu) (Plate XXVIII, Fig. 5), and a triangular pattern, termed leko, is used for food (Plate XXVIII, Fig. 6). Baskets are often waterproofed by means of a thin covering of wood and clay. Neither weapons nor pottery are covered with basketwork.

Pottery is made by women, and is an art learnt from the Ba-Huana. The wheel is not in use, the pot is built up on a base, some old vessel serving as a stand on which it is turned round and round. The ordinary pot, dzungu, is made in different sizes, varying in diameter from 13 to $41 \mathrm{~cm}$. (Plate XXVIII, Fig. 3). The edge is "flared," and below it is an ornamental band of incised parallel horizontal lines; no painted decoration is applied, either before or after firing. Gourds are used as substitutes for pots. Pots and pipes are the only articles made of clay; the former are broken on graves.

Pigments used are red, pale violet, white, and brown clays; the first two are eaten also. Articles to be dyed undergo no special preparation beforehand, they are simply immersed in the solution. As has been said before, the favourite colour is red.

Metallurgy. - The only metal which is not imported is iron, the ore of which is found throughout the country in great abundance, and small ingots are used as currency (Kimburi). Smelting and forging have been learnt from the Ba-Huana. The metal when smelted is not subjected to any treatment beyond hammering, except in the case of the "steels" which are used with flint for procuring fire; these are wrapped in certain herbs, the identity of which is a carefully-guarded secret, heated to a high temperature, and thrown into cold water. The tools of a smith consist of the double bellows, similar in pattern to those employed by the Baluba and a T-shaped hammer with a pointed handle. It is practically impossible to obtain a specimen of these hammers, since death is the portion of a smith who 
parts with his tools. No stone implements are found, and no legends point to a time when metal was unknown. A smith teaches his trade to his nephew, who also inherits his tools. It would be idle to attempt to speak of the social position of smiths among a people where social distinctions are hardly yet recognised.

Engineering.-No earthworks or palisades are found ; even bridges, constructed of creepers and very frail, are rare, but it must be remembered that throughout the country there are hardly any streams which cannot be crossed by wading.

Conservatism.-As might be gathered from their backward condition, the $\mathrm{Ba}$ Mbala are strongly opposed to any change; as an instance of conservatism may be mentioned the fact that though they have numbers of flint-lock guns they only use them for the purpose of making a noise, and only in rare instances for war or hunting.

Housebuilding proceeds as follows:-Stakes, of about $2 \mathrm{~m}$. in length, are driven into the earth at a distance of about $15 \mathrm{~cm}$. one from the other. These are so arranged as to form a rectangle, approximately $2 \mathrm{~m}$. by $4 \cdot 70 \mathrm{~m}$.; over these grass is bound, and the whole receives a covering of palm-leaf ribs, bound tightly together; the roof is ridged and thatched with straw. The only opening is the doorway, the "threshold" of which is situated $1.30 \mathrm{~m}$. above the ground; the door is rectangular, made of palm-leaf ribs bound together, and is shut by being slid between the wall and two stakes fixed to support it (Plate XXIX, Figs. 3, 4 and 5). Fetishes are affixed to the wall above the doorway.

It is reached by two steps, each composed of two forked stakes driven into the ground and supporting a crosspiece (Plate XXIX, Fig. 6); these steps are $0.25 \mathrm{~m}$. and $1.00 \mathrm{~m}$. from the ground respectively; there are no windows, and no verandah. The interior arrangements are simple ; there is no special place for the fire, the smoke of which escapes through the door. The house is divided into two compartments, a large room in the front for adults, and a small one at the back for children. An arrangement of stakes and matting serves as a bed, and along one of the longer walls runs a palm-rib shelf, attached by one edge to the wall, the other supported by two strings fastened to the roof. This shelf is used for storage; weapons are hung on the wall. Houses usually face more or less north or south; every village has a house for the use of travellers where the unmarried men lodge. There is no difference in the houses of slave and freeman, and no special building for cattle, which find a lodging as best they can. Granaries are built only by the rich ; these are on piles, and circular, with a diameter of $50 \mathrm{~cm}$.

Neither pile-houses nor cave-dwellings are found ; latrines are unknown; pigs and dogs remove the refuse which is thrown behind the house.

TRADE.

The chief currency in this region is the small shell called djimbu, ${ }^{1}$ and

1 Mr. E. A. Smith, of the British Museum, has kindly identified a sample of this shell as olivella nana. He further remarks: "It is known as a West Indian species in some monographs. I have reason to doubt that locality. It was collected by Dr. Walwitsch in West Africa, and it is quoted as "West African" in Tryon's monograph. I can find no more definite distribution of the species." 
relative values are as follows :-100 djimbu are equivalent to one fowl, or onethird temo (iron hoe-blade), or one big or two small kimburi (quadrangular iron blocks), or 330 grammes of salt; one male slave $=10,000$ djimbu; one female slave $=15,000$ to 20,000 . These djimbu are certainly of Portuguese importation. The ordinary measure is "a basketful," and all baskets are of approximately the same size. The Ba-Mbala are great traders, and show considerable aptitude for this occupation; a man will buy goats in Kolokoto and sell them for rubber in Lukula; the rubber is sold to Europeans for salt, the salt exchanged for slaves, the slaves sold for djimbu, and more goats bought in the country where they abound.

Thus 8,000 djimbu purchases ten goats; for these 250 balls of rubber are obtained; the rubber is worth $62 \frac{1}{2} \mathrm{kgs}$. of salt, which can be exchanged for two slaves; two slaves fetch 20,000 djimbu, with which 25 goats can be bought; thus a profit of 150 per cent. can easily be obtained, in the ccurse of about a month. In the case of food and pottery, the trading is carried on by women. It cannot be said that labour is regarded as derogatory; and skill in handicraft is respected as a means of acquiring wealth; even chiefs are not ashamed to be smiths or basket-makers, though their natural preference is for trade.

Markets are sometimes established on the neutral ground between several villages, where an important chief has buried his kissi, or fetish.

The system of credit is well known, not only short credit from one marketday to another, but for longer periods. Interest is enormous, amounting to cent. per cent. at three months, and the debtor usually stays with his creditor until the debt is paid off. If eventually he cannot pay he becomes the slave of his creditor. Slave-children, slave-wives, slaves, and cattle of the debtor can be seized by the creditor, but the latter's chief usually interferes and lends him money at a tremendous rate of interest to pay off the debt; thus it often happens that the greater number of the inhabitants of a village become the slaves of their chief. If the debtor dies, his brother must discharge the debt; there is no claim on the corpse. War often follows the non-payment of debts, and traders of the same tribe as the debtor are seized and often killed. No trading language is used except Kikonge, and that sut rarely. Middlemen are not paid, but make their own profit by cheating both sides.

\section{Social Organisation.}

The system of government found among the Ba-Mbala is extremely elementary; it might be described as communism with a strong flavouring of anarchy. The unit is the village community, at the head of which is a Fumu, or chief, who holds that position by reason of his wealth in slaves and wives. Upon his death the power devolves upon the individual who comes next in riches; there is no form of election. No tribute is paid to the Fumu, but he has several privileges, including the right to receive: $(a)$ the ribs of every man killed for food, and (b) a hind leg of each beast killed during the common 
hunts. His principal duty is to lend money to his "subjects" when they have incurred fines which they are unable to pay, and, consequently, are in danger of becoming slaves.

Women and children cannot hold the office of Fumu, and it may be taken as a rule that men by the time that they become chiefs, have attained the age of, at least, thirty years. Villages are small, and it often happens that a man, who has become rich, leaves his village with his wives and slaves and a few relations, and establishes a village of his own, with himself as Fumu.

Although society is in an embryonic stage, there is one form of compact which deserves mention; the most powerful, that is, the richest chief of the neighbourhood, will invite the rest of the chiefs in his vicinity to a meeting held on his territory in order to make a pact against bloodshed. A slave is fattened for the occasion and killed by the host and the invited chiefs and their followers partake of the flesh. Participation in this banquet is taken as a pledge to prevent murder. Supposing that a chief, after attending an assembly of this kind, kills a slave, every village which took part in the bond has the right to claim compensation, and the murderer is sure to be completely ruined. For the procedure in such cases, see under JusticE.

An alliance between two chiefs is contracted by making incisions in the breast of each and rubbing the blood of the other into the wounds. In this case death is the penalty for killing a man belonging to the village of the other.

Muri.-Perhaps the most remarkable fact in connection with Ba-Mbala social life, especially when the primitive nature of their organisation is considered, is the existence of a class of men called Muri. These Muri may not eat human flesh, nor the flesh of fowls; they are distinguished by a fine iron bracelet, called Mwena, which is worn on the arm, and a head-covering of cloth. Great importance is attached to both these ornaments, the head-cloth may not be removed by anyone, should a man do so, even by accident, he is liable to be killed; the Mwena cannot be purchased, ${ }^{1}$ but passes, at the death of the Muri, to his nephew, when the following procedure must be observed: The deceased is buried for about two months; after this his skull is exhumed, painted red, and placed in the house he used to occupy. The heir to the Mwena must steal this skull at night, without being observed, and, after hiding it a few days in the bush, take it home to his hut as a trophy. If a Muri is slain in battle, and the enemy become possessed of his corpse, they detach the arm bearing the Mwena from the body before preparing the latter for food, and return the bracelet to the dead man's tribe, to be given to the rightful heir. Wrongful appropriation of a Mwena is followed by instant death. The origin of this institution is shrouded in mystery, the natives say that it has existed "always"; no new Mwena are now made, so the number of Muri is limited and cannot be increased. The title Muri is prefixed to the name of the individual, e.g., Muri Kongo.

As a general rule all the freemen are more or less akin; kinship is reckoned

2 "I have offered what is considered a small fortune for one without success." 
very far on the female side, in the male line, not beyond the uncle and grandfather. The control of the family is vested in the father, but, when a man marries, his father-in law assumes paramount importance. In fact, it often happens that in war a man sides with his father-in-law against his own village. Genealogies are not reckoned beyond the grandfather, but the recognition of relationship, undesignated by accurate terminology, is carried very far.

Each married woman inhabits a separate hut, which she shares with her small children up to the age of three or four years. The husband changes residence every day, visiting his wives in turn. Women are regarded merely as a variety of domestic animal, but the household is usually peaceful, chiefly owing to the natural inactivity of the Ba-Mbala. No clans or corporations exist.

Marriage.-Two kinds of marriage are known: (a) Child marriage: a little boy, of his own free will, may declare that a certain little girl is his wife; by this simple act he acquires a prescriptive right to her. He visits his future parents-inlaw and takes them insignificant presents. When he is of mature age, he gives a larger present, of the value of about 2,000 djimbu, and then he is allowed to cohabit with her. Their children belong to the eldest maternal uncle. This form of marriage is attended by no special ceremony. If the girl, when of age, is unwilling, he cannot coerce her, but if she marries another man, the latter must make him a present of several thousand djimbu. (b) Adult marriage : this is simply a matter of purchase ; the price of a wife is from 10,000 to 15,000 djimbu, paid to the ownerfather or maternal uncle-of the bride. In this case the children belong to the father. Should the woman die, not only is the money not refunded, but the husband is often forced to undergo the poison ordeal. Polygamy is common, but all wives have equal rights. Polyandry does not exist, but a childless man will secretly introduce his brother to his wife in order that he may have a child by her; such a proceeding is, of course, a secret de polichinelle. The children of a slave-woman belong to her master, who may or may not be her husband. After the birth of a child, the man must abstain from his wife for about a year, during which time the child is suckled; he may then resume intercourse with her after asking his fatherin-law's permission, which is granted upon payment of Kutusa Mwana, a present of two goats. It is believed that an infraction of this rule would prove fatal to the woman, and, in the event of her death soon after childbirth, the husband is accused of being the cause and heavily fined, or, more often, compelled to submit to the poison ordeal. Wives follow their husbands, but a man often takes up his abode in the village of his father-in-law. Parents have very little authority over children, who leave them at an early age.

Morality, in our sense of the word, can scarcely be said to exist; virginity is not considered of the slightest importance, consequently unmarried women indulge freely from a very early age, even before they have reached maturity; one result of this is that solitary and unnatural vices and prostitution are unknown; but, on the other hand, sexual excess is having an evil effect upon the mental and physical characters of the race. Celibacy is rare, in fact only the result of poverty 
or ugliness amounting to deformity. The lending of wives is not practised. (See also under Reproduction.)

Divorce is frequent; a man may repudiate his wife at will, and she may not again marry or even have intercourse with a man. Women can only rid themselves of their husbands by running away to a hostile tribe, by whom they are sold as slaves, and, indeed, often repurchased by their former husbands. In having recourse to this measure they run the risk of being killed and eaten by the tribe to which they have fled for refuge.

Widows can be claimed by the brother of the deceased; otherwise, if free women, they return to their parents and are allowed to marry again.

\section{SLAVERY.}

Three-quarters of the population are slaves; in fact, a chief really owes his position to the fact that he has acquired rights over the majority of his villagers by lending them money to pay their debts.

Slavery may be either congenital, or acquired (through debt or capture in war), theoretically the master has power of life and death over his slaves, but as bloodshed is forbidden this power is merely nominal. Slaves are exceedingly well treated and are considered the children of their owner ; they do not work harder than freemen, are usually provided with wives by their master, can possess property and other slaves, and can purchase their freedom if their estate of slavery is acquired and not congenital. They stand on the same footing as other property, and their master is responsible for their debts. There is no distinctive mark of slavery. When a man buys a new slave, he ornaments him on the first day with his best clothes and ornaments, and walks round the village with him to show him to his friends.

\section{Property.}

Everyone can own property ; land is owned by the chiefs, or rather, a man who owns land becomes a chief; the renting of land is unknown.

There are no landmarks, but the owner of a piece of land buries a fetish there. As a matter of fact anybody can own land. ${ }^{2}$ The owner of land has no right to the crops if raised by the labour of others, but he can, in the first instance, prevent the latter from establishing themselves there. Game can be hunted in the ordinary way over any land, but the great hunt when the grass is burnt is the privilege of the land-owner. Ownership exists as far as ponds and lakes are concerned, but running water has no proprietor.

A man's property is inherited by the eldest son of his eldest sister, or in default by his eldest brother; widows cannot inherit. No one can dispose of his property after his death by will, but he can, of course, give it away in his lifetime. Guardianship is known; the maternal uncle, Lembe, acts in this capacity.

1 "I really believe that they form, as a general rule, the happiest class among the population."

2 "I myself have bought a hill on which to establish a market after having buried my fetish there."

VoL. XXXV. 


\section{Miscellaneous.}

The word of salutation is Moyo, but if two Ba-Mbala meet they do not use it, they simply stop and talk. The ordinary form of address is Gwass, uncle, that for chiefs, Tata, father. Personal names are changed at puberty, and afterwards as often as the owner pleases; there is no particular harm in using the old name. It is a sign of goodwill to offer Kola-nut to the traveller; on presentation to a chief the traveller is offered Kola-nut and palm-wine, the chief drinks first and passes the cup. Little consideration is shown to the aged, in fact, the word "old" is considered as something of an insult. The natives bathe when they come across a brook or river, and wash every day about noon; a fibrous stick is used for cleansing the teeth.

\section{Education and Psychology.}

Parents have very little control over their children, who leave them early; they are left to learn by themselves, and as they are nearly always admitted to the company of the "grown ups" this is not difficult. They can hardly be said to play at all in the sense that we give to the word, but as they grow up they take part in rat-catching and the rest of the day's work. They are very precocious, and, up to the age of puberty, are often astonishingly intelligent; after puberty, however, they become exceedingly apathetic; sexual excess and continual intoxication by palmwine contribute largely to this result.

Few Ba-Mbala know any language other than their own; they have a thorough geographical knowledge of their country but are unable to draw maps. Their powers of observation are not great and they are not good trackers.

Their memories are good only so far as the wiongs done by or to their ancestors are concerned; at their milonga (palavers; p. 414) crimes committed three generations back are frequently mentioned and remembered by the hearers. As regards arithmetic they are poor; they count generally in fives, and use small pieces of stick to make their meaning plain.

The numerals are as follows :--

$\begin{array}{llllllrl}1 & \text { Mosh. } & 4 & \text { Gwana. } & 7 & \text { Samboeli. } & 10 & \text { Gumi (Kumi). } \\ 2 & \text { Mbali. } & 5 & \text { Lanu (Tano). } & 8 & \text { Kinana. } & 20 & \text { Makumali. } \\ 3 & \text { Satu. } & 6 & \text { Sambanu. } & 9 & \text { Libwoa (Livvoa). } & 100 & \text { Kama. }\end{array}$

Ordinals are not used. Counting is usually done on the fingers; they talk very freely of a thousand and ten thousand djimbu, but if an amount such as fifty beads is mentioned, they ask to see them in order to be able to judge how much it really is. They cannot add, and subtraction can only be managed by means of the fingers, even by people of more than the average intelligence. ${ }^{1}$

1 "I tested a man as follows : he brought me six fowls for sale, and I had three removed without his knowledge; I then asked him how many I had to pay for, and he was unable to tell me." 
Sticks are used as follows:-for instance, in reckoning time, if one man wishes to make an appointment with another in so many days, he begins, "Tomorrow (Lakela) you do not come," and lays down a stick, "The day after to-morrow (Lun $\alpha$ ) you don't come," and lays down another. "Then for one day you do not come," laying down another, "For one more day you do not come," and so on, putting aside sticks until the total is reached. When he has finished, the other counts the sticks, adds one, and says, "For so many days I shall sleep and then I shall come and see you."

Here may be inserted a few remarks on the native year. A year is composed of two seasons, the dry, Kisua, and the rainy, $V u l a$; the two together are divided into thirteen lunar months, each consisting of seven weeks of four days each. The days are :-Bujuka, Moshila, Gundu, and Pika (market-day).

There are no names for the points of the compass, stars, or constellations, nor is any explanation given of the motions of the heavenly bodies, eclipses, earthquakes, etc. The rainbow is called Kongol-Meme (water-snake).

No cases of insanity appear. ${ }^{1}$

Writing, strictly, is of course non-existent, but messages can be sent by means of an arrow, on which certain marks have been cut; the latter, however, seem to admit of considerable latitude as regards interpretation; for instance, four notches may mean "Come and see me in four days," or "I shall come and see you in four days," or "Send me four men," etc.

Music.-The Ba-Mbala are fond of music, but in this, as in everything else, they show a conservative spirit, since they sing no foreign songs, only their own. The men have good tenor voices of small compass, the women soprano; both the chest and head voice are used. As a rule singing is unaccompanied by instrumental music, but a native will often sing softly to himself, while playing on one of the only two instruments, besides the drum, which they possess, the "piano" with iron or bamboo keys, Kimbenda (Plate XXIX, Fig 1), or the harp, Sabe. They seem to enjoy this greatly, and hold the instrument close to the ear in order to "hear more of it." Singing is often in chorus, men and women singing alternate verses, and all joining in together at intervals. The song commences as follows:-

\section{(Recit.) A Voice: Kimbanda, moyo. \\ Chorus : Moyo. \\ A VoICE : Kimbanda, moyo. \\ Chorus : Moyo.}

Then follows the song, the words of which are invariably of too obscene a character to bear repetition. All the tunes sound solemn in spite of the words, but are very elementary, in fact Ba-Mbala music may be described as rhythmical noise without coherence; as often as not the singers are out of tune. Below is given the music of two songs.

1 "I know of no case of insanity, but it is possible that the mentally afflicted are put out of the way, in which case Europeans would not be likely to hear of it." 

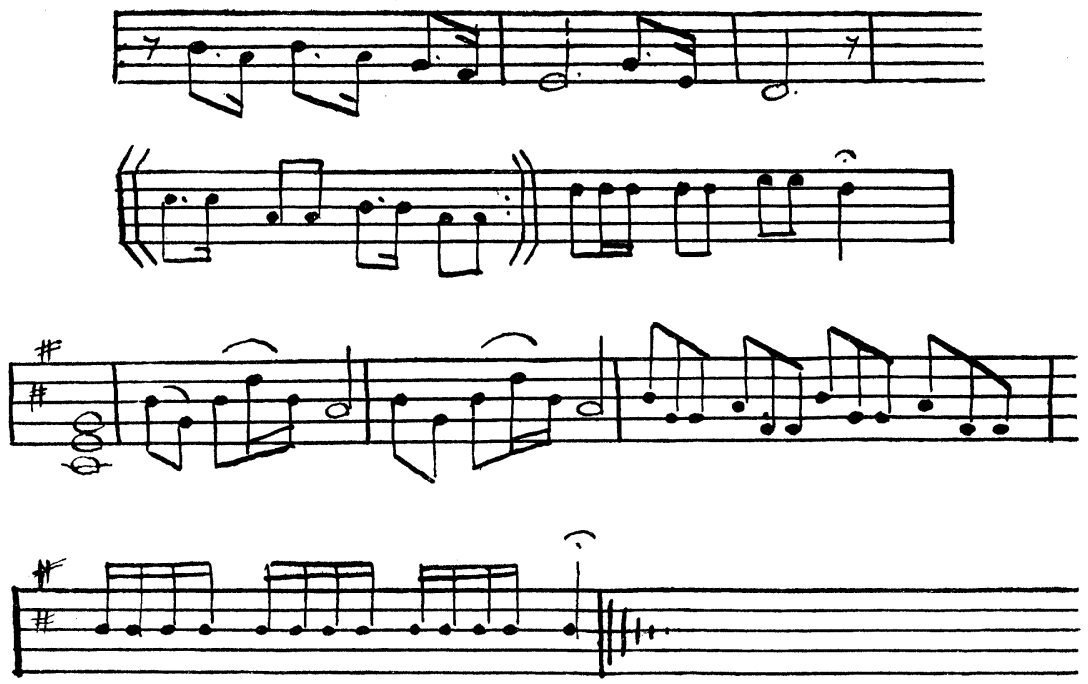

Drums are of wood, and cylindrical, the membrane is formed by a goat-skin stretched over one end ; they are used for accompanying the dance. There is also a particularly large pattern, called Molangi, which is used in war. Whistles of wood, often with a finger-hole by means of which a second note can be obtained, are used in war and hunting (Plate XXIX, Fig. 2).

\section{JUSTICE.}

The administration of justice among the Ba-Mbala may be summed up in the single word Milonga (palaver); round this system their whole life centres, and all disputes, whether between two Ba-Mbala or a Mo-Mbala and a member of a neighbouring tribe, are settled by this institution. In explanation of the proceedings a typical case, such as occurs every day in this country, may be given. $A$, of the village $X$, steals a goat belonging to $B$, of the village $Y$. Under pledge of the greatest secrecy, he boasts to some friend of his feat, and the result is that before the end of the day $\mathrm{B}$ knows who the thief is. $\mathrm{B}$ then sends a messenger to A asking for Kama-Kumi, that is, a few djimbu, a little salt, a fowl, or in fact, anything of little value. If $A$ refuses, and this is rarely the case, war is made on his village; if, as usual, he consents, it means that he admits the crime and is willing to accept responsibility for the act. B's next act is to send an arrow to A's chief, marked with a number of incisions indicating the number of days in which the Milonga will be held. When the day arrives, not only the whole population of the villages of $A$ and $B$, but of all the neighbourhood, flock to B's village, all armed with bows and arrows (in this respect custom differs from the proceedings on the Lower Congo), to take part in the trial. There is no judge, but the decision is left to the crowd. Men of noted eloquence speak on behalf of each party, and the discussion begins. A admits that he has stolen the goat, but did not B's grandfather seduce his, A's grandfather's, wife? B allows this, but asserts that his father had a fowl stolen by A's grandfather. A does not deny the offence, 
but recalls the fact that a pig was stolen from his uncle by a slave of B's grandfather's brother-in-law. And so the case proceeds, the assembly declaring after each charge and counter-charge that the matter is compensated. Eventually he who can bring the greater number of charges against his adversary is declared the winner, and claims compensation. This gives rise to a further discussion; if one demands twenty goats the other offers one, and the argunent often lasts several days, but they generally arrive at some agreement at the end of it; on the rare occasions when they cannot come to terms war results. It often happens that the man who demands the Milonga loses his suit.

If a goat is stolen from a neighbouring village, pieces of the flesh are sent to the villages allied to the village of the thief; the idea being that if war results, and, consequently, the allies have to run the risk of being killed, it is only fair that they should have had some of the spoil.

In murder cases each village which has joined the bond described under "Social Organisation" demands the Kama-Kumi, and proceeds by means of the Milonga. In cases of parricide the Kama-Kumi is not asked, but war is decláred against the village of the murderer ; after several people have been killed,-and the accused need not necessarily be amongst them-a Milonga is summoned to decide the question of compensation. The chiefs have no right to interfere at the Milonga, and children are punished as well as adults. If the dispute is between members of the same village recourse is usually had to the Putu, or poison ordeal.

As general rule every crime except parricide and diabolical possession can be compensated by a fine. An oath is taken by a man rubbing his chest with earth or licking his own arm, but it is of little value.

In this connection a few words may be said concerning general morality; sexual morality has already been discussed, but it may be added that adultery is a purely personal offence. A man who does not treat his slaves well is despised by everyone; avarice is generally disapproved, but there is no law of hospitality towards tribesmen or others. Hemp-smoking is also considered a disgrace, but drunkenness is mentioned with respect as a sign of wealth. Cheating and lying are rather approved than otherwise; cowards are merely laughed at. There is no belief that the gods or spirits punish wrong-doing by afflicting the criminal or his family, nor are the acts of a man supposed to affect his condition after death.

\section{WAR.}

War is declared by the commission of an act of hostility, usually consisting in an attack upon a member of the hostile village. Two kinds of war are knownthe small war, Kutana, and the great war, Gembi. For the first a special arena is cleared by burning the grass, but if a man is killed in the ensuing engagement the Kutana becomes Gembi, which is fought when and where enemies meet. Every male over the age of eight or ten takes part; women hide in the bush. Leadership of a more or less purely formal character is assumed by the chief, if young enough, in the other event by one of his sons. As regards the Kutana the warriors, armed 
solely with bow and arrow, march in single file to the appointed spot; arrived there, they insult each other for some time, and then commence to shoot, sometimes attempting enveloping movements; they show considerable courage and also dexterity in avoiding the arrows of the enemy, and as a rule little harm is the result. The Gembi is a far more serious affair, no quarter is given to the wounded, and women and children are killed if caught; ambushes are prepared, and every form of treachery is practised. Each man fights for himself, and does his best to kill any enemy; warfare is of the guerilla type, and the enemy are never allowed a moment's peace. No words of cornmand are used in either form of war.

Bows and arrows are of local manufacture, the former are made from a kind of maple, called Mopelenge, and are very well carved; the string is pulled by means of the index and middle fingers. Arrows are nocked and feathered (Plate XXVIII, Fig. 8); the heads SECTION OF BOW. are not intended to come off in the wound, and no poison is used.

Wooden weapons, the ends sharply pointed and hardened in the fire, are also found, and slivers of bamboo are stuck in the ground to wound the feet of the enemy. Defensive armour is unknown; women have no weapons and do not know their use. Night attacks are made, and during a war no one sleeps in the house, but all are on the alert; the village is guarded by a large number of sentries. The chief causes of war are:- $(a)$ breach of the bond against bloodshed; $(b)$ refusal to give Kama-Kumi when guilty of theft or adultery: in the first case Gembi results forthwith. In Kutana prisoners are secured by the Taka, a heavy stick with a fork at one end, in which the neck is fastened, sometimes they are further fettered by securing one hand to a large log with a hole in it, called Kalombi. They can be ransomed, but if the price is not forthcoming they are sometimes eaten. Whistles, similar to those used in hunting, are employed in war (Plate XXIX, Fig. 2).

As regards plunder, everyone takes what he can; there is no such thing as effective conquest, since the Ba-Mbala desire no territory.

\section{Poison ORdeal.}

The poison, called $P u t u,{ }^{1}$ used in the poison ordeal is made from the bark of a tree, imported from the mouth of the Kwango. It usually acts very quickly, and in one of three ways, causing death, evacuation, or vomiting; the first is the usual result, and, as well as the second, is taken as a proof of guilt; the third alone establishes innocence. In a dispute either party can propose to take the Putu, but the test is most frequently applied in the case of an individual accused of being Doki, i.e., possessed by Moloki, the evil spirit, and of being thereby the cause of some one's death. The accusation usually falls on some person who is old and rich, or for some reason unpopular, and men do not hesitate to denounce their nearest relatives.

1 The Director of the Royal Botanic Gardens at Kew, to whom a fragment of the bark was submitted for examination, has kindly indentified it as follows: "the sample received for identification is 'sassy' bark (Erythrophloeum Guiniense), a full description of which (as Erythrophloeum Judiciale) is given in the Pharmaceutical Journal, vol. xvi (1856), p. 233." 
After the poison is administered the bystanders call Moloki for ten or fifteen minutes, the time usually required for the operation of the drug.

Throughout a great part of Ba-Mbala-land the Putu is ground into a fine powder-like flour, and mixed with a little water to form a thick paste; from this paste are made five small loaves, each about the size of an almond, which are administered one after the other, accompanied by invocations to Moloki. Unless vomiting intervenes, the guilt of the accused is regarded as established. In any case, if there is no result beyond natural evacuation, the person thus declared guilty is made to dig a hole in the ground; he is then given a fowl to eat, and sufficient palm-wine to make him thoroughly intoxicated; after which he is laid, or in some cases goes and lies down, in the hole, and is buried alive. This is done to prevent the Moloki escaping with his last breath. On the grave a large fire is kindled which is kept alight for two days; the body is then exhumed and cooked with manioc flour. In the somewhat rare event of an individual being proved innocent, he is decorated with beads and carried about in the village in great triumph for two or three days, and the accuser, unless a witchdoctor, must make him a present of a pig as compensation.

\section{Death and Buriat.}

Every man has a soul; it is invisible and inaudible, but is capable of doing harm; it is continually wandering about in the form of some animal, and if this animal is killed the owner of the soul dies. Another cause of death is the Moloki, which for convenience of expression may be translated "devil." Possession by Moloki is frequent, and the possessed uses his power for the destruction of others. (See later under ReLigion.) After every natural death an accusation of being possessed by Moloki is brought against someone, usually elderly, who is forced to undergo the poison ordeal. Accusations of this kind are very frequent, and a man will often accuse his parents or his brother. When a man dies the body is, at first, deserted by everyone; later it is stretched out, painted with white clay, and exposed for several days, finally it is wrapped in cloths and buried in the earth with the feet to the east.

Women lament for several days over the dead, and guns are fired to keep off the Moloki.

Near relations and people who have nothing to do take part in the burial. A goat is killed and half of it is buried with the corpse, the rest is eaten. It seems probable that in former times the victim was a slave. As the soul does not eat, the burial of part of the victim with the body is simply a mark of respect. Pots are broken on the grave, and a semi-cylindrical hut, $2.20 \mathrm{~m}$. long by $75 \mathrm{~cm}$. high, is erected over it (Plate XXIX, Fig. 7).

Next follows a period of mourning, during which the inhabitants forsake the village and sleep in the open: women paint themseives with brown clay as a sign of mourning, men with soot; the hair is allowed to grow and is not shaved again until the number of parasites render this necessary. The soul after death is supposed to wander about, and, if the grave is neglected, to disturb, or 
even cause the death of, the relations. If satisfied about the condition of its grave, it takes the form of some animal, that of a chief of a large beast, those of the rest, of animals corresponding in size to the importance of the deceased. Children before puberty have no soul, neither have plants, food or weapons. The name for soul is Mityima, the same word as is used for " heart"; besides entering animals, souls also wander about in the air; they are indestructible. Ghosts return and seize people by the throat (nightmare). Burial customs are the same in all cases, no matter what the rank or sex of the deceased. No one is refused burial. The dead are soon forgotten.

\section{ReLigion.}

If questioned on the subject, the Ba-Mbala admit the existence of a supreme being whom they call $Z a m b i$, but no one takes any notice of him; it seems almost certain that he is an imported deity and has been borrowed from the Ba-Kongo. An interesting light is thrown on this point by the following fact: in the interior, where a knowledge of Ki-Kongo is found, the phrase is often heard, "I will come when $Z a m b i$ is dead," the word in this case meaning the sun. Now the people from whom they acquired their knowledge of Kikongo, in speaking of Zambi, must have pointed to the sky, and the Ba-Mbala, seeing nothing but the sun there, naturally formed the erroneous conclusion that the sun was meant. At any rate there is not the very slightest trace of sun-worship.

The true native "god" is a malevolent being named Moloki, who is in fact "ein Geist der stets verneint," and all respect is paid to him. $\mathrm{He}$ is omnipresent, but is wont to select as his particular abode the body of some old man, rich for preference, or some old woman who possesses an evil tongue, and to his agency natural deaths are attributed.

It is very difficult to get the natives to speak at all about Moloki, and, further, to arrive at any very clear idea about him when they do. It seems a little uncertain whether he is regarded as one or many; he is usually mentioned in the singular, yet we find the Doki, as the person possessed by the Moloki is called, being buried alive in order that the Moloki may not escape with the last breath, a fact which would seem to imply that there was more than one. The Doki is attributed with various reasons for exercising his fatal power; it may be that he has some wrong to avenge or he may think that a child is too intelligent, or, again, it may be from pure malevolence. In any case he proceeds to carry out his nefarious plan as follows : he steals the Mityima (" heart" or "soul "-for belief concerning this, see above under DEATH AND BURIAL) of his victim, who is quite unconscious of the loss, and puts it into a goat, the goat's "heart" he puts into the man, and as a man cannot live with a goat's "heart," the victim dies; the goat, however, continues to live. Sometimes the Doki binds the Mityima he has stolen to a tree, where it is invisible, and waits for the ants to come and eat it, in which case the victim dies; if for some cause the ants leave it alone, he is saved. $\mathbf{A}$ curious story is that sometimes the Doki preys upon the hand or foot of his victim, and 
the member so attacked falls off. This may refer to cases of leprosy which do occur among the natives in the interior.

Magicians vary in importance, and also their prices in direct ratio; there is the "country practitioner," who is content with a moderate fee, and also the "westend specialist," whose prices are enormous ; for an unimportant piece of magic his fee is 1,000 djimbu, but when he comes with his big fetishes it is three or four times that amount. The great magician among the Ba-Mbala, a man of wide reputation, is Mwana N'Gombe; Mwana = "the child," and N'Gombe is the name he gives to his three great amulets. These are : $(a)$ a Mwena bracelet; $(b)$ an axe also called Mwena; and (c) his head-dress, a piece of eloth in which certain fetish compounds of extra special power are kept; it is ornamented with cowries, and he is not allowed to see it, or his death would instantly and inevitably result; for this reason he is never allowed to look in a mirror. Mwana N'Gombe is a good-looking and intelligent man; if called by his name, he replies "Gale," a word the meaning of which is a great secret and is known to no one. When he laughs he hisses loudly between his teeth, a performance which greatly impresses the natives.

Fetishes are carved from wood, but receive their power from the Kissi applied by the magician; this Kissi is composed of clay or earth which he has inherited from his predecessors. Mwana N'Gombe received his from his uncle, and when he dies will leave it to the son of his eldest sister. He claims to be the inspired servant of his $K i s s i$, and alleges that when divining he does not know what he says, the Kissi speaks through him. He treats sick persons by the application of charms : for instance, if a man has a pain in his side he takes a goat's rib, and binds it against the part where the pain is felt; the rib is then supposed to draw all the sickness from the spot affected. To show the method of divination it will be best to take a concrete instance: a child dies of, say, over-eating; the fatality is immediately attributed to the malign influence of Moloki acting through some possessed person. An important witch-doctor is summoned, and the conjuring begins. He sets up his two great fetishes in the middle of the circle of onlookers, and begins to question them in a low voice, the bystanders accompanying him in a very subdued chorus. These fetishes consist of two wooden figures, male and female, on which he has put his Kissi, and the length of the consultation depends on the amount of the fee, for he does not give more than the money's worth.

"No, he did not die of snake-bite. No, it was not his mother who killed him," and so forth, unill at last the witch-doctor begins to shiver: "I see an old man, with a white beard, living in this village, wearing a brass ring on his left great toe, who is possessed of Moloki: he it is who has caused the child's death !" The old man in question, who is guilty of no other crime than wealth and long life, at once protests his innocence, and offers to take the Putu in proof of his assertion, and this is administered in the usual way (p. 416).

Every family possesses Kissi which has been inherited, and this is used in several ways. For instance, a creditor makes a line with it on the arm of a 
man who owes him a debt, and the Konzi, as the line is called, may not be removed until the debt is discharged, and, until this be done, the debtor cannot hope for prosperity. More than this, the debtor will make no attempt to efface the Konzi, but will try his best to raise the money to pay what he owes. ${ }^{1}$ Crystal-gazing and the divining-rod are unknown. Some chiefs retire to drink, being unwilling that anyone should see them.

\section{REPRODUCTION.}

Males have intercourse at the age of about ten years, the age of puberty; girls, from the age of six or seven, before menstruation; the position adopted is usually side by side. There is no special season of the year for marriages. Men abstain from their wives during pregnancy. There are no means of saving the child if the mother dies in childbirth. The child is suckled about eighteen months, sometimes by women other than the mother, but solid food is given when the child is four months old. The method is as follows: the child is placed upwards in the mother's lap, and a small quantity of Kato (see FooD) is pushed into its mouth; the child usually protests vigorously and tries not to swallow it, but is compelled to do so by having more crammed into its mouth.

Monsters and cripples are buried alive, but there is no special treatment for twins. A woman usually has three or four children. The kola-nut is used as an aphrodisiac, and sterility is rare; a sterile man is called Mokobo; a sterile woman Wafa Kisita. Causes tending to keep down the population are war and cannibalism.

\section{MEDicINe AND SURGERY.}

The ordinary complaints are bronchitis, fever, and syphilis; elephantiasis and leprosy are known. Diseases are supposed to be cured by the use of charms. Wounds heal readily; they are treated by the application of certain herbs, the knowledge of which seems confined to a few old people, who also know how to set a broken arm or leg; blood-poisoning is rare. Bleeding by cupping is the most common remedy, and is of universal application; small gourds are used, from which the air is exhausted by suction through a small hole at the top, which is then stopped up. Infection with syphilis is not punished in any way. The pulse is said to be a nerve and is not connected in any way with the heart or the soul.

\section{ABNORMALITIES.}

Albinos exist, but are not treated differently in any way from the normal native; spotted individuals also occur, and red hair is not unknown. ${ }^{2}$ Hare-lip,

1 "A striking instance of the superstitious regard for the Konzi came under my personal notice; a man put the Konzi on the door of the hut of an enemy in a village at a considerable distance from his own. Since that time, every death in that village was attributed to the influence of the Konzi. I made his son remove it, and for this service he received a present of ten goats."

2 "I have heard of a boy, about ten years old, who, though black, had red hair and brown eyes ; he was accused of being possessed by Moloki and killed." 
cleft palate, tongue or cheek, deformities of the extremities and steatopygia, appear to be unknown.

\section{LANGUAGE.}

The language of the Ba-Mbala is very elementary; there is practically no grammar, and the sentence is little more than a mere agglomeration of words. Below is appended a short vocabulary, which will be found to vary in some small respects from that published in $\operatorname{Man}, 1905,75$. The difference is explained by the fact that the latter was collected on the Kwilu, in the north of the Ba-Mbala territory, where the neighbourhood of the Ba-Yanzi and Ba-Huana has had a considerable influence upon the Ba-Mbala dialect; the vocabulary given herewith was obtained further south, in the interior of Ba-Mbala-land. It may be added that there is a word expressing affirmation, $D_{o}$; if a man is asked, Wei Zako Lo? "Are you not coming?" he will reply, Zako Do, "Yes, I am coming." If he were not, he would reply, simply, "Yes," meaning "Yes, I am not coming."

\section{VOCABULARY.}

\section{Personal Appellations.}

Ancestor, kake.

Aunt, paternal, tata.

Brother, makuni.

Chief, fumu.

Child, mwana.

Cousin, kisoniki.

Drunkard, kufula-makana.

Father, tata.

Father-in-law, ukwa.

Friend, bai, futer.

Infant, mwazi-mwazi.

Insulting expressions, fokoy, inzai, kimbundu gamei, kong, mobaremei.
Man, mutu.

Mother, nei.

Mother-in-law, ukwa.

Nephew, mokakana.

Rebel, mayuma.

Sister, pangi.

Slave, mwika.

Thief, mwima.

Uncle, paternal, gwass.

Uncle, maternal, lembe.

Woman, mokosoma.

\section{The Body.}

Anus, moshishi.

Bone, ikuri.

Breast (of woman) mari.

Buttocks, matako.

Calf, dombola.

Chest, kingongo.

Clitoris, momburi,

Ear, n'jwe.

Eye, meso.

Eyebrows, kiki.
Eyelashes, konge.

Fæces, duji.

Fingers, dembe.

Foot, mile.

Gleet, kikangala.

Hair (of body), maka; (of head), dupu.

Hand, miyoko.

Head, mutu.

Heart, mityima.

Hunger, pai. 
Leg, mikulu.

Mouth, kanu.

Navel, djimba.

Neck, kota.

Nose, mozulu.

Palm, pape koko.

Penis, inzai.

Rib, sakati.

Shoulder, yambande.
Skin, pela.

Sleep, tulu.

Smallpox, matuba.

Syphilis, makwanda.

Testicle, makuta.

Thirst, pwiza.

Tongue, limi.

Tooth, mazu.

Vagina, bundu.

Weapons, Utensils, and the House.

Arrow, betutu; wooden-pointed, tomo; iron-pointed, mivi; four-pointed, kikashi.

Bag, godi.

Basket, kisangi; square-based, mahapa; -lid, bango; -base, muteke.

Bead, misanga.

Beam, mokambo.

Belt, mokamina.

Bottle, bungu.

Bow, buta; button at end of, kimbundu; string, lokako.

Box, mokobe.

Cage, n'gunzu.

Cloth, native, kipussu; imported, molele.

Door, towale.

Fetter, for hand, kalombi.
Fork, for prisoners, taka.

Gong, war, molangi; dance, gomo.

Gourd, mundele.

Granary, kiango.

Hat, jepi.

Hoe, demo.

House, $n^{\prime} z o$.

Knife, poko.

Mat, lizana.

Mortar, mushi.

Pipe, bamboo, fangu; European shape, kinzu; gourd, motobo.

Pot, dzungu.

Roof, yange.

Sieve, muswalu.

Snare (for birds), muhetu.

Thatch, bamba.

Village, $m^{\prime} b o$.

The Animal World.

Animal, situ.

Ant, tumwena.

Antelope, bambi.

Bat, miswuese; large, gonzu.

Bird, nyuni; small, gunda.

Boar, wild, sumbu.

Buffalo, natyi.

Chameleon, yokniyi.

Dog, m'boa.

Eagle, lokoli.

Egg, maki.

Eggs, maikiri.
Elephant, dzoko.

Falcon, kokori.

Feather, sala.

Fish, ashi.

Fowl, kok, susu.

Goat, kombo.

Goliath beetle, gombo.

Grass-hopper, passa; large, moyei.

Guinea-fowl, kanga.

Guinea-fowls, akanga.

Hippopotamus, gufu.

Honey, buik. 
Horn, lubongo.

Kite, $i m b i$.

Leopard, koy.

Lion, tambo.

Louse, anzenga.

Milk, mari.

Monkey, kima.

Parrot, kusu; small, green, with red head, kirinkusu.

Partridge, kwali.

Pig, gulu.
Pigeon, domestic, mayembe; green, gundundu; grey, mayembe.

Ral., puku.

Various kinds of rat, banga, belele, kakala, kashingi, kibengi, kilima, kitupi, moebo, pali, sabila, shinji, tanga, vuinda, zwanga.

Screech-owl, kikungulu.

Snake, nyoka.

Turtle-dove, bembe.

\section{The Vegetable Kingdom.}

\section{Banana, tichipi.}

Bean, makundu.

Brushwood, miti.

Capsicum, dungu.

Forest, misiti.

Grass (for thatch), bamba.

Ground-nut, n'zuku.

Maize, masa.

Manioc, soko.

Mushroom, boko.

Palm-tree, $m^{\prime} b a$; -nut, $m^{\prime} b a$; -wine, makana.
Pepper, kief.

Pineapple, $i b a$.

Pineapples, $b i b a$.

Plantain, mipindi.

Sweet-potato, mato-nc-singa, sengesenge; red, kata n'donge.

Timber, for building, makunda; small, ile.

Tobacco, magaya; for snuffing, fuma.

Wood, midono.

Yam, kusu-m'bongo.

Time, the Elements, and Geography.

Air, funji.

Clay, humi, pembe.

Day, mafuku.

Days of the week, bujuka, moshila, gundu, pikc (market day.)

Day after to-morrow, luna; day before yesterday, besukulwari.

Earth, toto.

Evening, pimpa.

Fire, $b a o$.

Forest, misiti.

Iron, dondo.

Lightning, dzaji.

Marsh, muchipi-chipi.

Moon, gonde.

Mountain, mosele.
Night, ofuku.

Plain, demo.

Rainbow, kongol-meme.

Road, bokc.

Sand, mana.

Season, dry, kisua; rainy, vula.

Star, mieto.

Stream, mokele.

Sun, mwano.

Time, sumbu.

To-day, mwanc.

To-morrow, lakela.

Water, memo.

Week, pika.

Wind, funji.

World, kifutu. 
Verbs.

Angry, be, kuwa kabu.

Be, wene; I am here, ami wena ha. Beat down, kubwisa.

Bind, kukanga.

Boil (v.a.) kulamba.

Bring, zotwale.

Bring forth, kowala.

Call, kolendika.

Carry, kusenda.

Castrate, kotota.

Choose, kozola.

Come, zako.

Copulate, kolakana.

Crush, kututa.

Cry, kwakala.

Cut, kuvuka.

Discuss, koza milonga.

Dispute, kunuana.

Draw (the bow), kolewasa.

Drink, kunia.

Enter, kwingila.

Fight, kumana.

Flee, kutina.

Fly away, kuvulumukc.

Forget, kujimbala.

Give, kufuta, kupeza.

Go, kwende.

Have (I, we, have), kweti; (thou hast, he has, you, they, have), kukete.

Hear, kuiva.

Hunt, kwenda kongo.

Impregnate, kufula.

Ill, be, kwinzcl.

Jump, kusangulukc.

Kill, kujia.

Laugh, kusza.

Leave, kwekc.
Lie, kufuta.

Lie down, kumoka.

Love, kuzola.

Mad, be, kwinza lach.

Mock, kutuka.

Pay, simbika.

Pick up, kotola.

Pursue, mulabi.

Return (v.n.), kindingisa.

Remain, kubika.

Ride, kunene.

Say, kwambala.

Seize, mokomoho.

Send, kutumisa.

Sew, kunuka.

Share, lukaba.

Silent, be, kuluka.

Sing, kutuba mokungo.

Sit, kubashi.

Smell, kisulu.

Smoke, kunya makaia.

Sleep, kubitca.

Speak, kwakula.

Steal, kwimbula.

Strike, kubula.

Swim, kokasa.

Take, senda.

Throw, wimbila.

Tired, be, kwela.

Travel, kukiba.

Truth, to speak, mopala lo.

Urinate, kusuba.

Wait, kuluka.

Walk, tambala.

Wish, kuzola.

Work, kuzala.

Wound, kulemenc. 


\section{Pronouns, Adjectives, Adverbs, etc.}

Above, na vulu.

All, akima.

Alone, mwene.

At once, tangri.

Beautiful, oketyi.

Below, na machin.

Between (two), kati-kati.

Bitter, ganyi.

Black, kubumbula.

Brave, woma-lo.

Castrated, tongo.

Cold, pio.

Drunken, kufula-makana.

Far, kutari.

Fat, maji.

Fierce, $k a b u$.

Good, pimbo.

Great, monene.

$\mathrm{He}$, yandi.

Here, $h a$.

I, ami.

Late, makirolo.

Little (adverb), kijigi-jigi.

Long, inda.

Male, bakala, molüme, yala.

Much, ingi-ingi; very, vula-vula.

Near, hei-hei.
No, lo.

Old, butakuna ; very, nunu.

Quickly, makiri, tsina-tsina.

Red, kubabala.

Satisfied, kukumbusa.

Slowly, tokoki-tokoki.

Small, mwazi-mwazi.

Soft, yeke-yeke.

Soon, kele-kele.

Sterile (man), mokobo; (woman), wafakisita.

Strong, golo.

Sweet, yeke.

There, $k o$.

They, bao.

This, yei.

Thou, $e i$.

Too, kuina. ${ }^{1}$

Very, bona.

We, betu.

Where, kwi.

White, kukubuka.

Wicked, kabu, ganji.

Yes, he.

You, benı.

Young, kalenge.

Number.

One, mosh (mosi).

Two, mbali (mbari).

Three, satu (tatu).

Four, gwana.

Five, lanu (tano.)

Six, sambanu.

Seven, samboeli.

Eight, kinana.
Nine, libwoa (livvoa).

Ten, kumi (gumi).

Twenty, makumali (makumari).

Thirty, makumi-satu.

A hundred, kama.

A thousand, funda.

How much, mukwa.

1 Only used with adjectives implying evil. 
426 E. TORday and T. A. JoYCE - Notes on the Eithnography of the Ba-Mbala.

\section{Miscellaneous.}

Bewitchment, konzi.

Currency, shell, djimbu; iron ingot, kimburi; brass rod, monengo.

Evil spirit, moloki.

Faith, madyafu.

Fear, woma.

Fetish, kiluba, kissi, konzi.
Hunt, kongo.

Market, pika.

Present, mokwala.

Salutation, "Moyo."

Skirmish, kutana.

Song, nokungo.

War, gembi. 


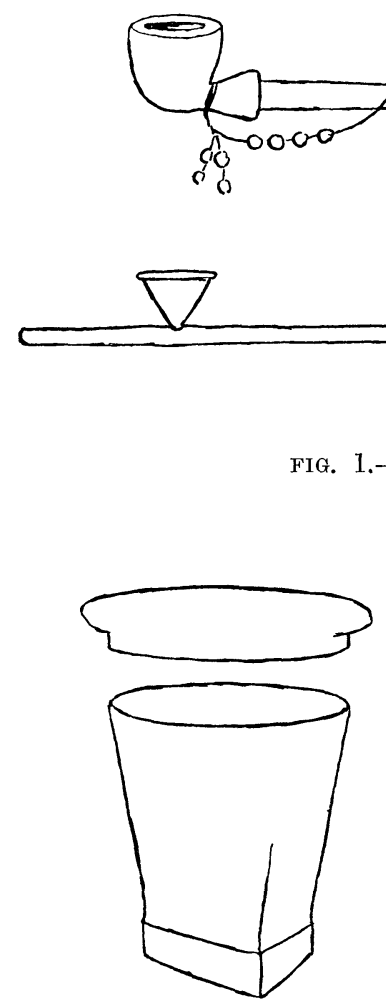

FIG. 4-BASKET (p. 406).

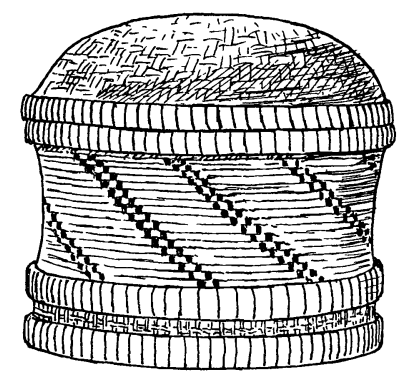

FIG. 5. - SMALL BASKET-PURSE (p. 406). Diam. $80 \mathrm{~mm}$.

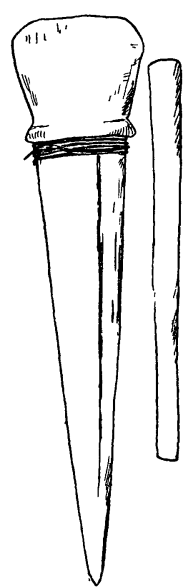

FIG. 2.--WOODEN MORTAR FOR GRINDING SNUFF (p. 405). L. $350 \% \mathrm{~mm}$.

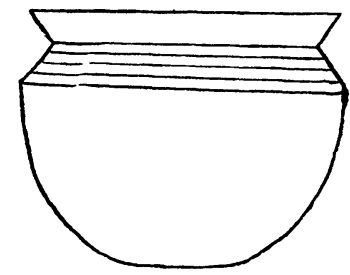

FIG. 3.-POT (pp. 403, 406).

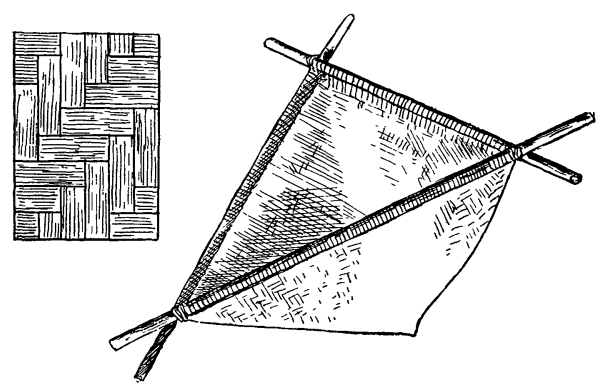

FIG. 6.--FOOD-BASKet (p. 406). Length of side $345 \mathrm{~mm}$.
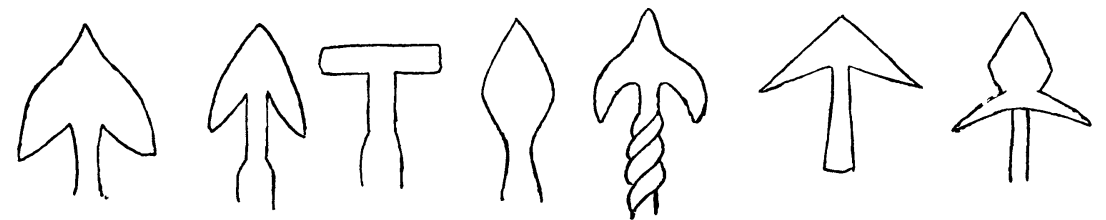

FIG. 8.-TYPES OF ARROW-HEAD (pp. 405, 416).

NOTES ON THE ETHNOGRAPHY OF THE BA-MBALA. 


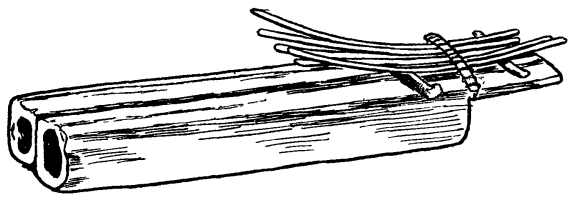

FIG. 1.-PIANO WITH SOUNDING BOARD OF PALM LEAF RIBS (p. 413). L. $244 \mathrm{~mm}$.

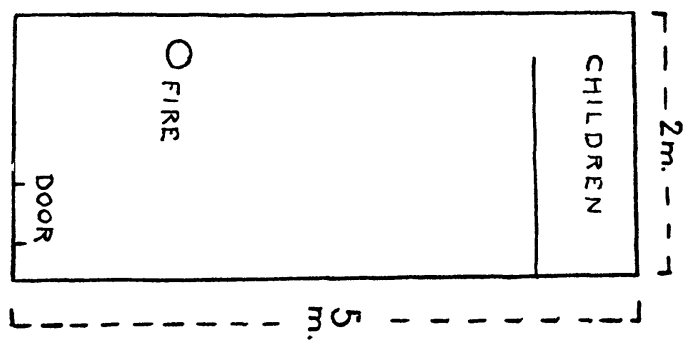

FIG. 3. - PLAN OF HOUSE (p. 407).

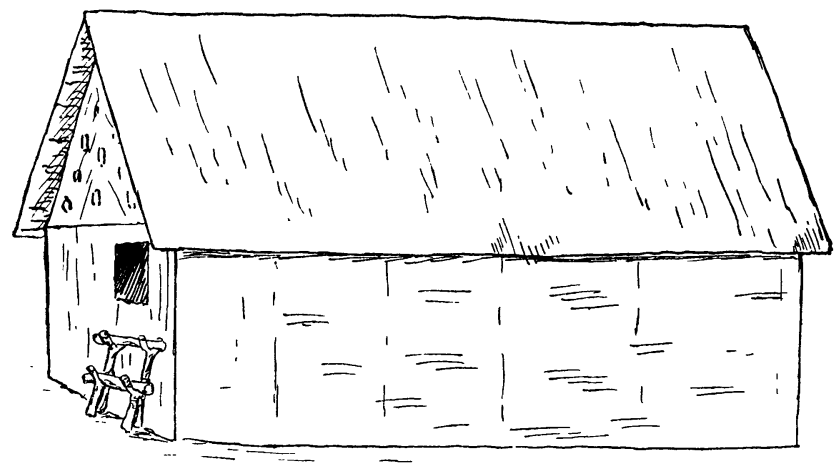

FIG. 4.- HOUSE (p. 407)

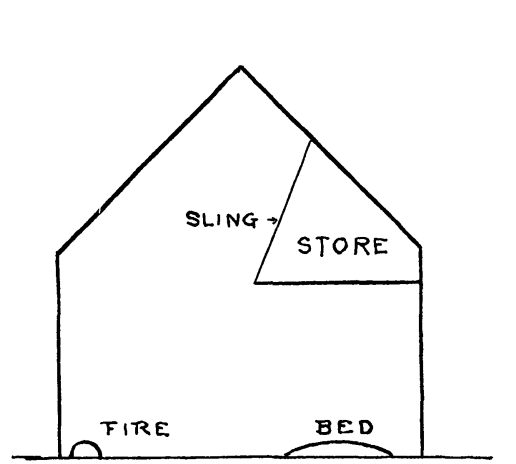

FIG. 5.- SECTION OF HOUSE (p. 407).

FIG. 2.-whistLe. (Blown from the lower end) showing finger-hole by means of which a second note is obtained (pp. 406, 414, 416). L. 150 mm.

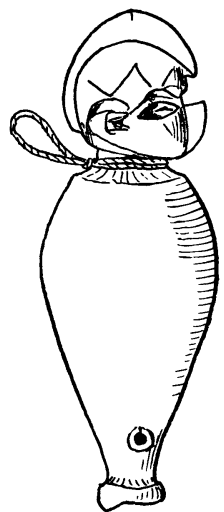

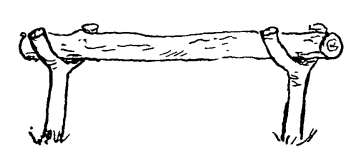

FIG. 6. -ENLARGED DRAWING OF $\operatorname{STEP}($ p. 407).

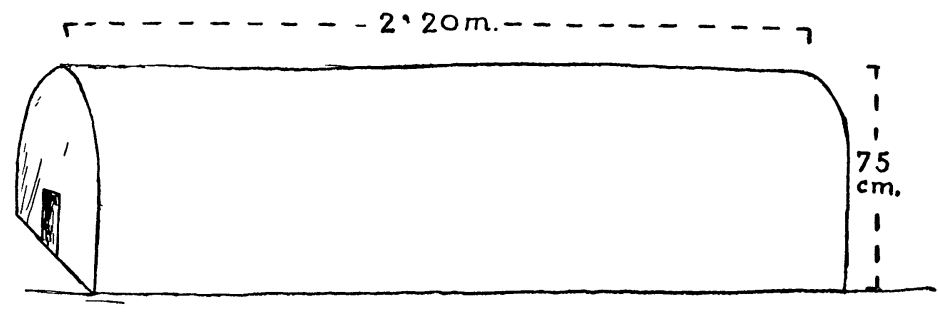

FIG. 7.-GRAVE-HUT (p. 417).

NOTES ON THE ETHNOGRAPHY OF THE BA-MBALA. 


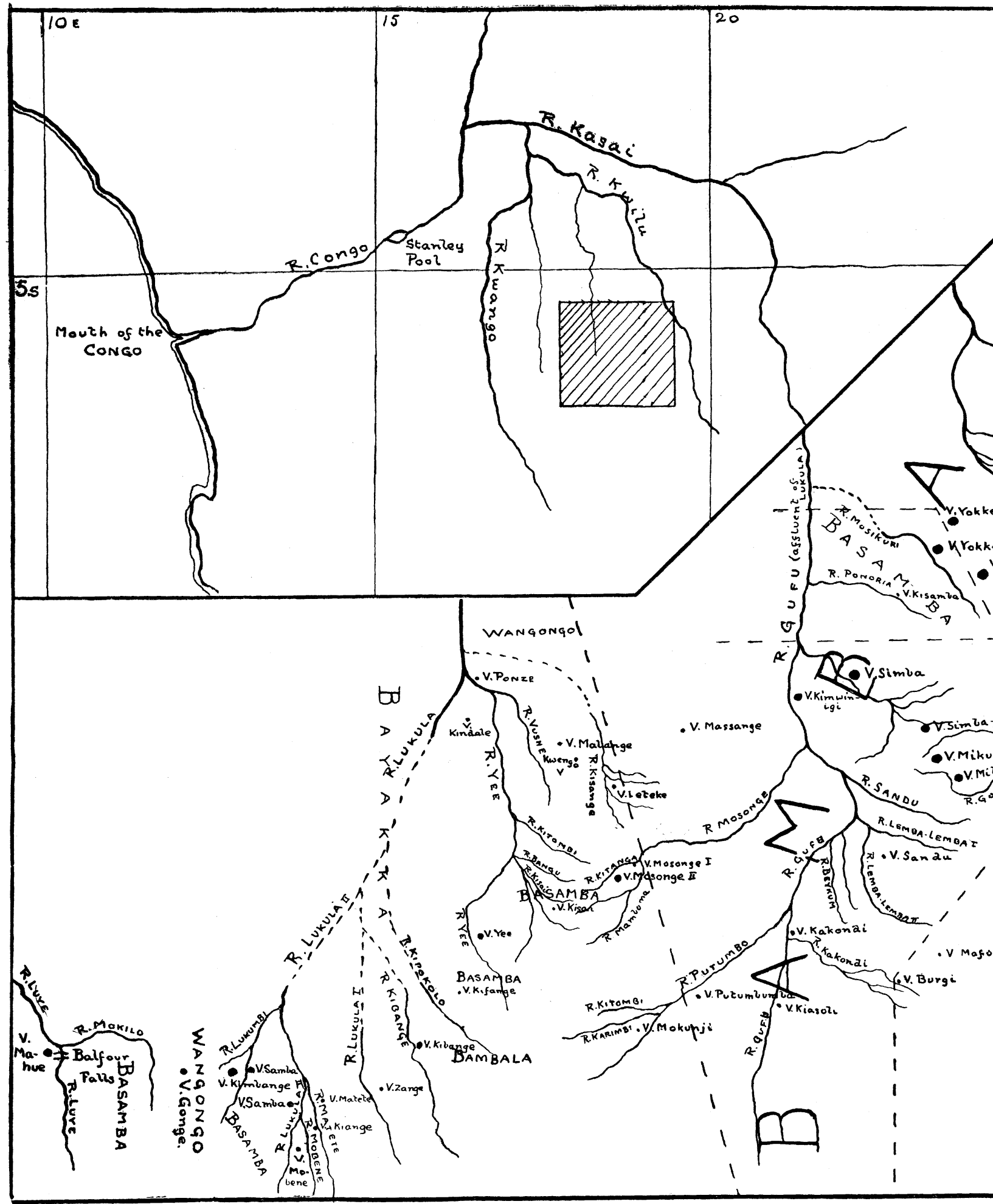

NOTES ON THE ETHNOGRAPHY OF THE BA-MBALA.

(Noтk.-v. = village. $)$ 


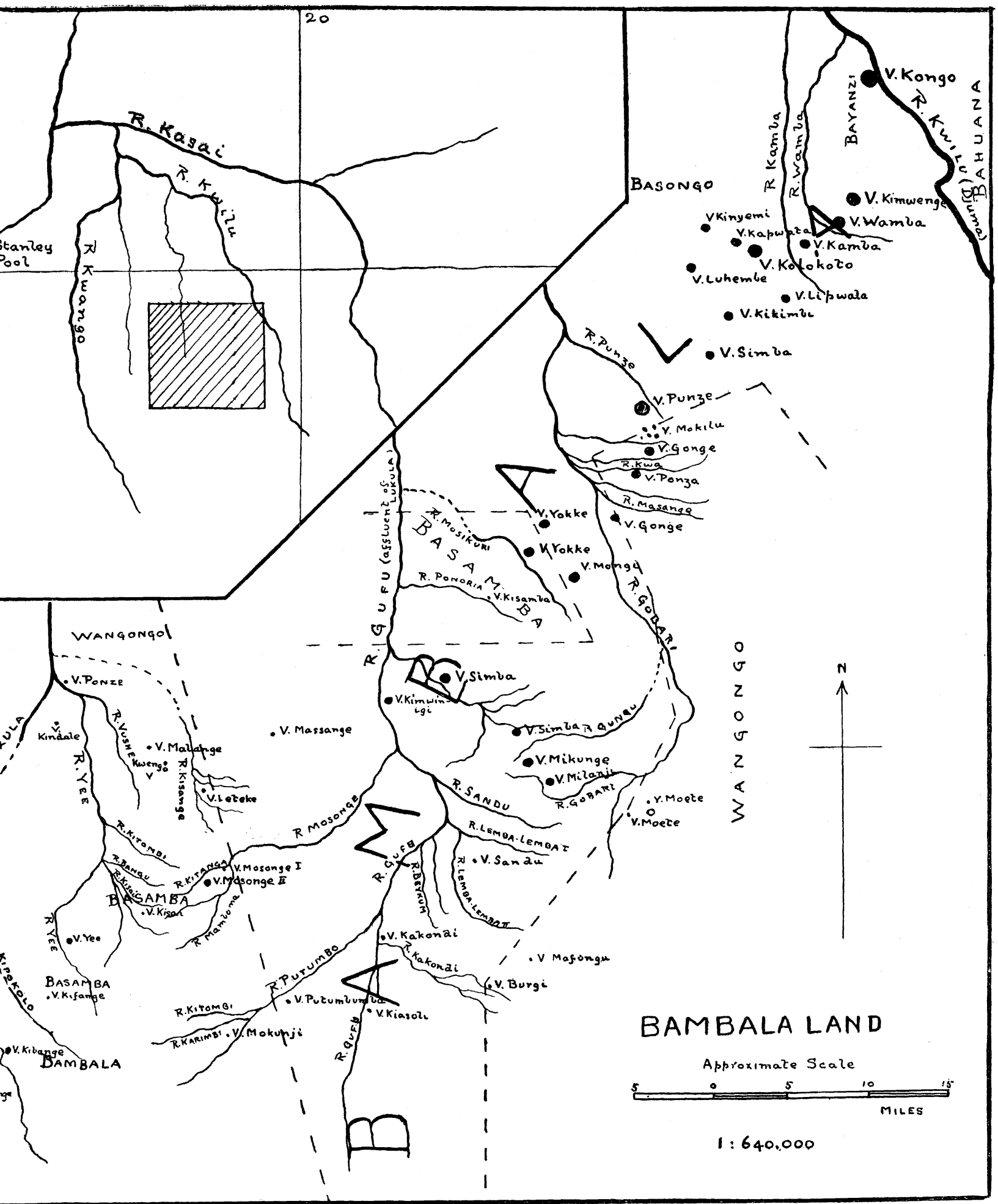

NOTES ON THE ETHNOGRAPHY OF THE BA-MBALA.

(Noтн.-v. = village.) 